\title{
Political apathy amongst students: A case study of Nelson Mandela Metropolitan University
}

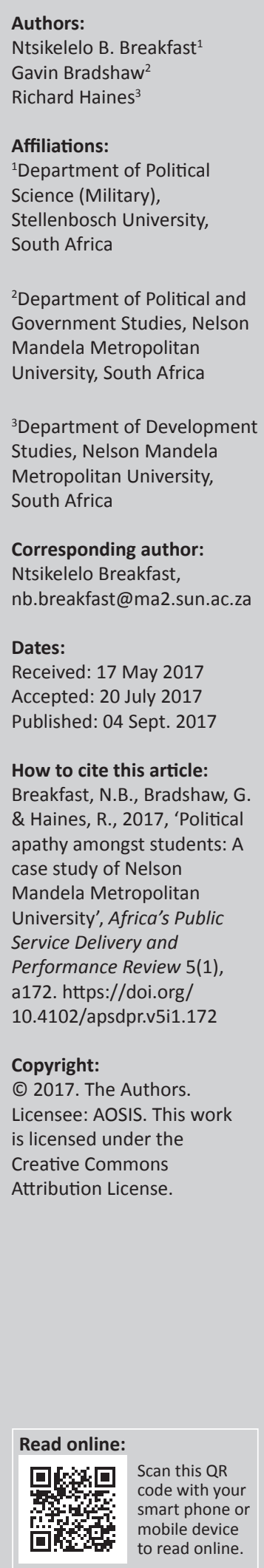

The primary motivation for this research, in which a qualitative method was employed, was to examine political apathy amongst students at Nelson Mandela Metropolitan University. The secondary motivation was to question whether youth political apathy threatens the consolidation of democracy. The researchers arranged four focus groups at Nelson Mandela Metropolitan University. A purposive sampling technique was utilised. All 50 participants in the study were Nelson Mandela Metropolitan University undergraduate and postgraduate black students, with ages ranging from 21 to 35 years. The researchers encouraged participants to have maximum participation in the focus group deliberations. The researchers also made use of elite interviews in the study. The findings of this study suggest that political apathy does exist amongst students at Nelson Mandela Metropolitan University. Most of the participants in the focus groups indicated that young people in post-apartheid South Africa have no interest in politics.

\section{Introduction}

Following the unbanning of the national liberation movements and the release of political prisoners in February 1990, the entire South African political landscape changed significantly. Subsequently, youth political organisations started to vigorously attack the media, scholars and others who so easily wrote off black youth as a 'lost generation' (Everatt 2000:2). The expression 'lost generation' in this context refers to young people in the new South Africa who are politically apathetic, materialistic, involved in crime, abuse alcohol and have a neo-liberal outlook on life. Levin (2005:90) writes that South Africa's third democratic general election in 2004 has been documented and analysed by both the media and academic intellectuals. He argues that the most interesting aspect of the 2004 election was the failure of the young people to vote and he points out that voter registration amongst the country's youth was very low in the 2004 national election. This leads one to conclude that political apathy amongst young people indeed exists in South Africa. Post-apartheid South Africa offers an opportunity to study some of the most interesting questions that are raised in the article.

Theorists such as Everatt (2005:89) have formulated some questions that stimulate our thinking around apathy, such as what the causes of political apathy amongst young people in postapartheid South Africa are and whether it matters if young people are involved in politics or not. From a political science viewpoint, these questions are very important in South Africa, because not much has been written locally about political apathy amongst young people. For this reason, the study on which this article is based was conducted to fathom the degree of political apathy amongst young people within the context of the consolidation of democracy. The primary motivation for this research was to examine political apathy amongst black students at Nelson Mandela Metropolitan University (NMMU). The secondary motivation was to question whether youth political apathy threatens the consolidation of democracy.

Levin (2005:91) asserts that young people are opting out of organised politics in order to take part in the 'pretty spectacle' of Adidas, BMW, Nike, Puma, Reebok, Levis and Calvin Klein. Young people in South Africa are apolitical and extremely materialistic. Furthermore, because of consumption-driven capitalism in post-apartheid South Africa, the youth have become disengaged from politics. Young people may have returned to the status of a lost or violent generation, but critically, they spend a lot of money, and they spend it mainly on fashionable, big names and expensive clothes. This is ironic, in a country such as South Africa, in which the youth played a historically important role in achieving changes through major political struggles. This makes one wonder seriously what this political apathy implies in terms of the youth's participation in future change (Dolby 2001:25; Everatt 2000:74). 
However, it must be noted that though one does acknowledge the scholarly evidence pointed out above, undeniably the 'body politics' has substantively changed with the political participation of students in the so-called \#FeesMustFall movement since 2015. This matter is touched by Baragwanath (2016:1) when she argues that the political activism of young people via the student protests between 2015 and 2016 was one of the hallmarks of democratic consolidation in postapartheid South Africa. Similarly, Hodes (2016:144) argues that the 'Fees Must Fall emerged as a national movement because of its successes in the mobilisation of mass numbers of students simultaneously, across various locations'. These complexities, namely youth political apathy and the recent \#FeesMustFall movement in higher education will be taken into account when teasing out the understanding of democracy by young people in the new South Africa. Amongst other things, the aim of this article is to critically examine the scholarship on the politics of the youth post 1994, in order to identify its strong points and weaknesses, and how it impacts on South Africa's consolidation of democracy.

\section{Research question}

The central research question of this research was: How does political apathy amongst students at NMMU impact on democracy and can democracy be consolidated without young people?

The central research question was answered by the data collected by the researcher; this is explained in the methodology section. A short overview of relevant literature on youth political participation during the era of apartheid is first presented.

\section{The development of black youth politics in South Africa}

It is imperative to examine the historical trajectory of youth politics when one seeks to understand the current problem that South Africa experiences in relation to youth political apathy. The main aim of this short overview is to discuss the ideological influences on young people during apartheid. There were a number of philosophical traditions which informed the orientation of youth politics in South Africa during the apartheid era. One of these philosophical traditions was Black Consciousness, which was greatly influenced by Steve Biko, Frantz Fanon, Marxism and Pan Africanism. Gevisser (2007:302) explains that after the youth had observed segregation in the education system of South Africa, Black Consciousness and Marxism were employed as tools of analysis describing the political situation in South Africa.

Frantz Fanon, in his seminal work titled The Wretched of the Earth, argued that every generation has a responsibility to take a stand against social injustice (1963:145). The youth of the 1970s used Fanon's work to critique the apartheid government in South Africa. Black Consciousness motivated the youth of 1976 to engage in mass action. The youth of 1976 were inspired by, amongst others, the youth of the 1940s who established the African National Congress Youth League, whose leaders included Nelson Mandela, Oliver Tambo, Robert Sobukwe, Walter Sisulu and Anton Lembede. Thirtysix years ago, on June 16 1976, thousands of Soweto high school learners took to the streets to protest against the government's intention to impose Afrikaans as a medium of instruction in black schools.

After 1976, many young people left the country to go into exile. Since their aim was to take South Africa by means of an armed struggle, they received military training. Some of them died in exile and others were hanged in South Africa. Young people in post-apartheid South Africa need to honour these heroes by participating in politics. If young people today do not participate in politics, it would mean that they do not acknowledge the contribution and sacrifices made by the youth of 1976 (Deegan 2005:53; Vagenas 1986:34). Amongst other things, young activists during the 1980s contributed to the propagation of the notion of nonracialism. According to Xolela Mangcu (2011:7), because of the absence of the PAC and Black Consciousness movement in the 1980s, both the United Democratic Front (UDF) and African Nation Congress (ANC) saw a gap to propagate its philosophy of non-racialism in SA. This is how the concept non-racialism gained momentum and became hegemonic in student politics.

The advent of democracy in post-apartheid South Africa has fundamentally changed the political landscape. Firstly, at this juncture young people in South Africa have rights; they can decide whether or not to participate in politics, unlike in the past where the political environment required people to be active. However, this does not imply that during apartheid all young people participated in the liberation struggle. Secondly, some aspects of globalisation have influenced the thinking of many young people in South Africa in relation to politics. By and large, most young people in the postapartheid era idolise the American lifestyle informed by neoliberalism, consumerism and globalisation (Breakfast 2009:75; Everatt 2005:89).

In approaching the subject, there is a need to understand the complex interplay of race, class and the imperial project. The conceptual suggestiveness of Marxian political economic extraction is of distinct use, or otherwise, the debate is grounded in a structured set of factors, overdetermined by the construction of race. According to Engels and Marx (1848:1), 'the history of all hitherto existing society is the history of class struggle'. This implies that social conflict is caused by the different interests of the working and ruling classes. The recent attacks on monuments in SA, in particular in institutions of higher learning is caused amongst other things by a 'class struggle' along racial lines. For instance, black students in historically white institutions, namely UCT, University of KwaZulu-Natal and Stellenbosch University, hold the view that inasmuch as the academic standards of these universities are high, they (the black students) do not yet have a sense of 
ownership of those universities, precisely because they happen to be part of the lack working class. Therefore, their values do not form part of the mainstream thinking of historically white institutions.

The attacks on monuments in South African universities were instigated by a group of young people who claim to be revolutionary in thinking and are calling for transformation, especially the appointment of black academic staff (in former white universities). This does not speak to youth political apathy though. On the contrary, it is an antithesis of young political apathy. These young people in historically white institutions have argued that young people in SA need to honour their political heroes by participating in politics. According to these students, if young people today do not participate in politics, it would mean that they do not acknowledge the contribution and sacrifices made by the youth of 1976. They hold the view that young people in postapartheid South Africa need to remember that the democracy they enjoy did not come cheaply; a price was paid for it and people laid down their lives for freedom (Deegan 2005:53; Vagenas 1986:34).

Scholars like Xolela Mangcu (2015:2) have argued that out of 4000 professors in the country (SA), less than 200 professors are black people because of institutionalisation of racism in South African universities. According to him, a substantial number of white academics (full professors) seat on the senate of universities and appoint people based on colour. Hence, the country has a shortage of black full professors. However, often the issue is not race, but the unfair advantage that impacts on the ability of humans to secure, fulfil or achieve basic human needs where they feel excluded or disadvantaged based on race. John Burton (1996:10) acknowledges that racialisation has an effect on human interaction in society.

The effects and abnormalities of racism have also be naturalised and normalised by some in society. For instance, there is a tendency to presuppose that a black person is no good but to work for a white person. This line of thinking is informed by the racist thinking that black people were made to work for white people only. Even though some of the black people who are bearing the brunt of economic exploitation have accepted their exploitation as a natural phenomenon as opposed to challenging the status quo. This demonstrates how sophisticated racism can be in society. According to Bobo and Fox (2003:319), there is sufficient evidence of scholarship that institutionalised racism is pervasive in society. However, not much research has been undertaken to examine the psychosocial effects of structural racism caused by power relations (Bobo \& Fox 2003:319).

Anthony Giddens (1993:254) points out that racial discrimination tends to affect members of the minority groups in society. According to him, minorities are normally subjected to racial prejudice and likely to be on the receiving end. However, there is a gap in this argument by Giddens. For instance, racism can be practised the other way around by the minority against the majority so long as there are 'power relations' at play. The apartheid regime was a minority (white) rule in SA over the black majority. What necessitated the situation was the grip the white people had over the state organs, 'national power' and the ownership of the means of production. This means that one does not need to be in the majority to practise racism.

Nonetheless, the argument about the correlation between power and racism has been misused by other politicians locally and internationally. For instance, proponents of Black Consciousness turned to argue that black people can never be racist because they don't have 'corporate power', meaning that they do not own the means of production. Paradoxically, racism can be practised by all and sundry based on racial prejudice.

For one, what is noteworthy is the relatively low level of interest by the working class and trade unions in the students' monument protests and the subsequent uptake of certain issues by the EFF. This is in part a reflection of the invocation of the colonial past by the protagonists as opposed to the new imperial present. The increased power of the multinational and transnational corporation, central to the growth of the new 'empire' in the 21st century (Hardt \& Negri 2000), remains at best tangential to the debates. The criticisms of the accumulative strategies of both old and new corporate elites in South Africa in the Marikana disaster do not appear to form part of the strategies for transformation.

Although Africanist, and to a lesser extent post-colonial, discourses appear as the main currents of thought informing the debates about statues, the dilution of such perspectives into more popular activism was also apparent. Social theoreticians, argues Giddens (2001), must ensure that there is a sophisticated and complex corrective to such dilution of theory. There is a dialogue then between the popularising, or even caricaturing, of theory, and the construction of more complex systems of thought.

Biko (1978:9), for instance, in his writings on the creation of more reflexive and authentic forms of black Consciousness, did not portray this as a zero-sum game. Rather it was about expanding options for black South Africans while allowing cultural space for others. It is noteworthy that earlier critical traditions had an expansiveness which should not be lost on the current generation (Hansen 2005). The challenge is for the space and ownership of such cultural objects to be diversified, not narrowed.

There is room for these differing theories, but in facilitating future and usually constructive debates, one needs to appreciate the need for substantive intellectual exchange and new synthetic theory rather than the narrowing of debates and the creation of self-contained and restrictive terrains of theory. Providing structures that accommodate intellectual exchange with proper praxis is of course a daunting challenge to high-end practitioners and academics working in the field of conflict and its management, but one that has to be grasped 
if the increasing scholarly emphasis on the conflict and development relationship is to be approached with due intellectual seriousness. The next discussion examines the methodological approach utilised in this study.

\section{Research methodology}

This study employed a qualitative approach, with the aim of providing an in-depth analysis of the issues at play in this research. Qualitative study is an attempt to understand people's perspectives, analyses and interpretations of a particular situation or context. The qualitative researcher, moreover, should attempt to become more than just an observer in the natural setting that is being examined. He or she also makes a deliberate attempt to put himself or herself in the shoes of the people under examination and scientifically study and understand the participants' actions, decisions, behaviour, practices and rituals from their own point of view (Babbie \& Mouton 2005:271; Leedy \& Ormrod 2001:153).

\section{Operationalisation}

The researcher operationalised the concept of political apathy by relating it to aspects such as the youth's membership of political parties, participation in elections, political involvement, political interest, comparison with the youth of 1976 and perceived government responsiveness to the concerns of the youth.

\section{Instruments for data gathering}

In the course of this study, 50 questionnaires were distributed to four focus groups. These focus groups were arranged by the researcher. The focus group discussions in this study were held at the Student Representative Council (SRC) offices, NMMU (south campus). The researchers in these focus groups included both men and women from workingclass and middle-class backgrounds. There were four focus groups in this study. Each focus group included 10 participants. The rationale behind this number was to make the discussions in the focus groups manageable. All the discussions were facilitated by Dr Ntsikelelo Breakfast, the principal researcher in this study. All participants were given an opportunity to speak in the focus groups. Deliberations in the focus groups lasted for two hours. All focus group deliberations were facilitated by the researcher. The questionnaire for this study included both open-ended and closed-ended questions. The open-ended questions provided primarily qualitative data in relation to the central research question and close-ended questions aimed to establish biographical data from the participants (McMillan \& Schumacher 2016:230; Pieterse 2004:9). Effectively, while the principal researcher was collecting data, saturation was observed during the early stage, with data substantially falling into certain categories; nonetheless, the whole sample was used.

The researcher also made use of elite interviews in the study. Each of the elite unstructured interviews lasted for 30 minutes.
More particularly, the researcher interviewed one political analyst, one historian, one economist, one professional psychologist and five young political leaders from various political parties. These political parties included Democratic Alliance Student Organisation, South African Students Congress and Pan Africanist Student Movement of Azania. The purpose of these elite interviews was to acquire an indepth analysis of the phenomena examined.

\section{Ethical measures}

Participation was voluntary in this study. Information from questionnaires, focus groups and elite unstructured interviews was kept anonymous in order to ensure confidentiality. Before embarking upon the study, the researcher explained orally that participation in the research was voluntary. Furthermore, the researcher explained to the participants that the study would not cause them any harm (Mouton 2013:240). Finally, the researcher pointed out to the participants that they would not receive any remuneration for their efforts.

\section{Data analysis}

Qualitative data analysis in this study was presented in the form of texts, themes, phrases, written words and direct quotations emanating from the participants. Audio tapes from the focus groups and individual unstructured interviews were transcribed verbatim. Hence, the researcher followed a qualitative content analysis technique. Content analysis is a systematic technique that studies the content of clear messages and how they are examined. In fact, it is more than just a systematic method; it is a technique of direct observation (Neuman 2003:438). The findings of this study are presented in themes below, followed by a summary made by the researcher. The participants' responses are quoted verbatim.

\section{Sample of the study}

The sample of this study consisted of 50 undergraduate and postgraduate black students aged 21-35 years at NMMU. It is worth noting that youth political activism in South Africa during apartheid was a political struggle of black people fighting for social justice. Because black people constitute the majority in our population, the focus in this research was narrowly concentrated on black people, and white people, mixed race people and Asians were excluded. Also, in order to provide a narrower focus, a concentration on the tradition of black protest made the study more manageable. Hence, the researcher selected only black students and excluded white students, students of mixed race and Asian students. More specifically, the researcher employed a purposive sampling technique. Purposive sampling occurs when a qualitative researcher wants to identify particular types of cases for indepth investigation (Neuman 2003:213). This means that the researchers have used their personal judgement in recruiting the participants. The researchers included both men and women from working-class and middle-class backgrounds. 


\section{Data analysis and interpretation}

\section{Theme: Political membership amongst the South African political parties}

'Young people in post-apartheid South Africa believe that the struggle is over and that there is no need for them to be involved in politics.' (Male, NMMU first year political science student, SRC member)

'If political parties would consider the problems of young people it would be worth being a political activist.' (Male, NMMU third year business management student)

Discussion: Forty participants out of 50 in the focus groups indicated that they did not belong to any political party in South Africa. They described involvement in party politics as boring and a waste of time. This shows that young people in post-apartheid South Africa are not interested in politics. Furthermore, only four of the participants regarded party membership as important. They also indicated that political apathy is a problem. Finally, six of the participants in the focus groups indicated that they had no idea what political membership is.

\section{Theme: Electoral participation}

The participants in the focus groups were asked whether they had participated in a local or national election. The principal researcher explained to the participants what is democracy, freedom, voter education and political campaigning. This aspect is important because elections are a cornerstone of democracy; without elections there is no democracy. Most participants in the focus groups indicated that they had never voted before in local or national elections, even though they had been eligible to vote. This aspect is emphasised by the following answers:

'Voting turnout in the 1999 and 2004 elections was very low amongst young people. This evidence leads one to arrive at the conclusion that political apathy amongst young people does exist in South Africa.' (Male, NMMU third year political science student)

'Political parties are not doing enough to encourage young people to vote for them.' (Female, NMMU second year sociology student)

On the other hand, all participants indicated that they would like to vote in the coming elections. However, one young woman felt that there was no point for young people to vote if politicians were not going to deliver on their promises. An Independent Electoral Commission (IEC) official indicated that 'elections are important for consolidating democracy'. Furthermore, he pointed out that the IEC at local government level did not have programmes that were meant to educate young people about elections'. The IEC officials at branch level are receiving instructions to educate only old people about voting. Also, political parties do not go to high schools and higher learning institutions to educate young people about the importance of voting.

\section{Theme: Political party membership}

Discussion: All participants in the focus groups indicated that electoral participation is important in deepening democracy. All of them agreed that refraining from voting is a problem, because elections provide people with the opportunity of choosing their own leaders. However, one participant was vehemently opposed to the above argument. The participant argued strongly that there is no point for young people to vote because politicians do not deliver on their promises. She went on to say that young people should stop voting because they do not benefit from the elections. One gets the impression from this young, intelligent woman that democracy only exists for business and political elites.

\section{Theme: Political involvement}

The participants were asked whether it is important to be involved in politics. Most of the participants in the focus groups agreed that politics is important in their lives. This aspect is emphasised by the following quotations:

'The youth has to be involved in shaping our democracy.' (Female, NMMU third year economics student)

This point is stressed by Heywood (2015:68) when he asserts that:

'the starting point from which to consider the nature of democracy is Abraham Lincoln's Gettysburg Address, delivered in 1884 at the height of the American Civil War. Lincoln extolled the virtues of what he called government of the people, by the people, for the people.' (p. 68)

'Politics helps you to know what is happening around you. Young people need to take a stand on sociopolitical issues. No country can succeed if it does not invest in the future of young people to become tomorrow's leaders.' (Male, NMMU second year public administration student)

'Politics broadens your mind to know your state better. Politics makes people know each other and discuss social problems. Politics influences our daily lives as young people and we must be able to understand what's going on, in our nation as young people because we are future leaders.' (Male, NMMU third year political science student)

Discussion: Of the 50 participants in the focus groups, 40 indicated that political involvement is vitally important. However, in this context, these participants seemed to be contradicting themselves, because initially when they were asked if they belonged to any political party in South Africa many of them said they did not. Five participants indicated that political disengagement is not a problem. Lastly, participants had no idea whether political involvement is important or not.

\section{Theme: Political interest amongst young people}

A participant expressed the following view:

'Young people feel it's a waste of time to be involved in politics. The youth of today is more interested in entertainment and popular culture. I suppose globalisation has influenced the 
thinking of young people in this day and age.' (Female, NMMU first year anthropology student)

'The political environment has changed in South Africa. Young people are not motivated by youth organisation to participate in politics. The problem is the black middle class. Most young people who have professions do not want to join trade unions due to their status. Most of these young people were taught in historically white schools, or let me say Model C schools. These young people were taught according to the Western culture of individualism; they do not see the relevance of politics in their lives.' (Female, NMMU second year economics student)

Elements of capitalism were evident in some statements.

Another participant commented as follows:

\begin{abstract}
'The problem is the education system of this country. It is capitalistic in nature and in character. It focuses on individualism, not on collectivism. The education we were taught is not objective, it reflects a particular ideology which is capitalism. It is selfish, has no love for humanity. Young people do not participate in politics; they only participate in economic activities such as entrepreneurship.' (Female, NMMU third year psychology student, SRC member)
\end{abstract}

'Individualism and cultural confusion are the causes of the political apathy. Young people have an identity crisis. This phenomenon leads to aggression and anger. After that young people blame culture, family and the community.' (Female, NMMU second year law student)

'Politics is boring; it is for old people not for us the young people. As young people we are busy with other things like sex, alcohol and money, we do not have time for poverty and unemployment.' (Male, NMMU first year economics student)

Discussion: Most of the participants in the focus groups felt that young people were not interested in politics. These participants indicated that young people in South Africa have a neo-liberal outlook on life. Elements of capitalism were evident in some statements. Forty-two of the participants indicated that a lack of interest in politics was a problem. On the other hand, six participants felt that lack of political interest was not a problem. They provided one reason: because South Africa is a democratic country in which young people have rights, political participation should be a choice not an obligation.

\section{Theme: The difference between the youth of 1976 and the youth of today}

The participants in the focus group were asked whether there is any difference in political thinking between the youth of today and that of 1976. All the participants in the focus groups felt that there is a difference between the youth of today and the youth of 1976 . This aspect is highlighted by the following quotations:

'The youth of 1976 were politically baptised by the youth of 1944 . These young people were prepared to die for freedom. Secondly, the youth of 1976 were opposed to the Bantu Education Act of 1953 and the use of Afrikaans in schools. However, young people in post-apartheid South Africa are facing different challenges like HIV and AIDS, poverty and unemployment.' (Male, NMMU first year economics student)
'The youth of 1976 could identify the enemy. They were prepared to lay down their lives for freedom. The youth of today are disengaged from politics.' (Male, NMMU third year political science student)

'The youth of 1976 were influenced by black Consciousness; they saw the independence of Mozambique as a sign of freedom. Young people today are not really free, due to poverty and unemployment. They should take a stand and involve themselves in politics. Political decisions affect everyone, including young people.' (Female, NMMU second year sociology student)

'The youth of 1976 were dealing with educational issues and apartheid. The struggles of the youth today are teenage pregnancy and the HIV and AIDS epidemic.' (Female, NMMU second year sociology student)

'Obviously, the youth of 1976's struggles are different from today's youth because the fight in 1976 was for the liberation of those who were oppressed by the apartheid system. Today the struggle is about economic freedom and crime eradication.' (Female, NMMU first year anthropology student)

'Activism is now a past thing. The youth of today are not politically active, not confident in themselves like the youth of 1976, and the youth of today are not informed about politics.' (Male, NMMU third year economics student)

Discussion: All the participants in the focus groups acknowledged that there is a significant difference between the youth of today and the youth of 1976. The participants indicated that the political environment in South Africa has changed dramatically and that young people at this juncture are facing different challenges such as HIV and AIDS, poverty and unemployment. Furthermore, all participants in the focus groups pointed out that the youth of today has lost the passion for politics. In their view this is a problem. Perhaps this lack of passion can be linked to capitalism as political disengagement in this day and age is often caused by entertainment, globalisation and individualism.

\section{Theme: Socioeconomic problems in Nelson Mandela Bay}

The participants in the focus groups were asked what kinds of problems were being experienced by young people in Nelson Mandela Bay. According to most of the participants in the focus groups, young people were faced with great challenges in Nelson Mandela Bay. The participants expressed their concerns in the following way:

'Unemployment is a major problem in Nelson Mandela Bay. How many university graduates are unemployed? The municipality is not doing enough in creating jobs for young people. Most of the government programmes that are meant to reduce unemployment are highly politicised. If you are not an ANC member then you cannot get a job in the municipality. This phenomenon discourages young people from participating in politics, because politicians are corrupt. They employ their own relatives.' (Female, NMMU first year public administration student)

'I will never vote for the ANC again because its leaders are corrupt. If you are a young woman and are beautiful you must have sex with certain politicians before you can get employment in the municipality. That is so unethical.' (Male, NMMU third year political science student) 
'Unemployment and poverty are the indicators of low service delivery in the municipality.' (Male, NMMU first year economics student)

'Young people in Nelson Mandela Bay are faced with a lot of problems such as poverty, unemployment, HIV and AIDS, substance abuse and inadequate education.' (Female, NMMU fhird year economics student)

'HIV and AIDS is a major problem amongst young people in the Nelson Mandela Metro.' (Female, NMMU first year anthropology student)

Discussion: The participants in the focus groups agreed that young people were being faced with great challenges in Nelson Mandela Bay. Unemployment, poverty, HIV and AIDS, alcohol abuse and crime were the major concerns raised by participants in this regard. The participants expressed the view that nepotism was not uncommon in the municipality. Participants were angry about the lack of service delivery by the Nelson Mandela Bay municipality. Finally, all the participants in the focus groups agreed that these socioeconomic challenges are a problem to young people.

\section{Theme: Government response to problems of the youth}

The participants in the focus groups were asked if the government was doing enough in responding to the problems of the youth. All of the participants in the focus groups felt that the government was not responding to the youth's problems. This aspect is highlighted by the following quotations:

'Government is emphasising internships and cooperatives; there are no social programmes for the youth.' (Male, Third year sociology student)

'Government does not seem to care about young people.' (Female, NMMU first year public administration student)

'This government is anti-poor. Look at the macroeconomic policy; it is a neo-liberal ideology. How can you talk about privatisation whilst black people are faced with post-apartheid problems such as poverty and unemployment? The ANC government has sold us out as black people.' (Male, NMMU third year public administration student)

'The government has not invested a lot of money in trying to combat socioeconomic problems amongst young people. Corruption and incompetence are a stumbling block in youth development.' (Male, NMMU third year political science student)

'The government is not really responding to youth problems. I think the government should embark on an extensive campaign on the importance of family. Family is very important in shaping the behaviour of a child. It is the first institution that influences the behaviour of a child. Young people do not have role models at home. Hence they do not care about political participation.'(Female, NMMU first year anthropology student)

Discussion: All the participants in the focus groups agreed that the government is not doing enough in responding to youth problems. Participants blamed the government for politicising the public sector. They raised issues of corruption and nepotism in government appointments. Finally, all the participants in the focus groups felt that the government's lack of response is a problem.

\section{Limitations of the study}

This inquiry focused only on black students at NMMU. It did not include white students, students of mixed race and Asian students at the university. Moreover, this study only identified NMMU students as participants in the research. Young people who are not students (unemployed and employed) were not included in the sample of this study. It is understood that a different sample might have yielded different results. In the next section the findings of the study are discussed.

\section{Conclusion and policy recommendation}

The research that informed this article demonstrated that by and large the students at NMMU do not belong to any political party and had never voted, even though they had been eligible to do so. This seems to indicate that young people have very little interest in politics. Capitalism was identified as the leading cause of political disengagement amongst young people post 1994. Furthermore, most of the participants in the focus groups were of the opinion that young people have no interest in politics. They perceived politics as boring and as a waste of time. Participants in the focus groups criticised the government for not listening to the people who had elected them. The other issue raised by the participants was the government's macroeconomic policy, growth, employment and redistribution. Most participants in the focus groups accused the government of implementing neo-liberal policies that are anti-poor. All the participants in the focus groups indicated that the government is not responding to the problems of the youth.

Because the research concentrated only on political apathy amongst black students at NMMU and included only black participants, I recommend that future inquiries on youth political apathy should include white people, Indians and people of mixed race. This could be done by employing both qualitative and quantitative methodological traditions. Furthermore, participants in future studies should include unemployed and employed young people and should not be confined to NMMU.

It is suggested that other topics and areas of research concerning youth politics should include the socioeconomic conditions of young people in post-apartheid South Africa. The IEC needs to develop a training programme that is designed to educate young people about the importance of voting. Furthermore, the government needs to consider establishing a youth ministry to focus specifically on youth issues. Amongst other things, this new department would look at issues such as the political involvement of young people, young people infected with HIV and 
AIDS, young people who are impoverished and young people who are abused by their parents and skills development amongst young people. This is a practical idea; for instance, Uganda has a very effective youth department that concentrates particularly on youth issues. It is suggested that this idea could be applicable to South Africa. In addition, it is recommended that political science and history be made compulsory subjects at high school level in South Africa. Making these disciplines compulsory will raise levels of political consciousness amongst young people. Kwaito and South African hip-hop artists should conscientise young people by composing and playing songs that have political messages. These songs should address poverty, unemployment, education, crime, moral values, entrepreneurship and HIV and AIDS.

\section{Acknowledgements Competing interests}

The authors declare that they have no financial or personal relationships which may have inappropriately influenced them in writing this article.

\section{Authors' contributions}

N.B.B. Project leader and was responsible for the design of the sample, data collection and the analysis/interpretation. N.B.B. also made some major conceptual contributions. G.B. and R.H. made some marginal contribution to the literature review of the study.

\section{References}

Babbie, E. \& Mouton, J., 2005, The practice of social research, South African edition, Oxford University Press, Cape Town.

Baragwanath, R., 2016, 'Social media and contentious politics in South Africa' Communication and the Public 1(3), 362-366. https://doi.org/10.1177/205704 7316667960

Biko, S., 1978, I write what I like, Picador Africa, Johannesburg.
Bobo, L.D. \& Fox, C., 2003, 'Race and racism and discrimination: Bridging problems, methods, and theory in social psychological research', Social Psychological Quarterly 66(4), 319-332. https://doi.org/10.2307/1519832

Breakfast, N.B., 2009, 'An investigation into political apathy amongst students. A case study of Nelson Mandela Metropolitan University', unpublished Master of Arts dissertation (Political Studies), Nelson Mandela Metropolitan University, Port Elizabeth.

Burton, J., 1996, Conflict resolution: Its language and processes, Scarecrow Press, Inc., Lanham.

Deegan, H., 2005, The politics of the New South Africa: Apartheid and after, Pearson Longman, Cape Town.

Dolby, N., 2001, Constructing race, State University of New York Press, Albany, NY.

Engels, F. \& Marx, K., 1848, Manifesto of the Communist Party, Political Pamphlet, London.

Everatt, D., 2000, 'The dead decade? Youth in post-apartheid South Africa', Development Update 3(2), 5-17.

Everatt, D., 2005, Growing up tough: A National Survey of South African Youth, Ravan Press, Johannesburg.

Fanon, F., 1963, The wretched of the earth, MacGibbon \& Kee, London.

Gevisser, M., 2007, The dream deferred: Thabo Mbeki, Jonathan Ball Publishers, Cape Town.

Giddens, A., 1993, Sociology: A brief but critical introduction, 2nd edn., Palgrave Macmillan, New York.

Giddens, A., 2001, Sociology, Polity Press, Cambridge.

Hansen, L. (ed.), 2005, The legacy of Beyers Naude, African Sun Media, Stellenbosch. Hardt, M. \& Negri, A., 2000, Empire, Harvard University Press, Cambridge, MA.

Heywood, A., 2015, Politics, 2nd edn., Oxford University Press, New York.

Hodes, R., 2016, 'Questioning "fees must fall"', Journal of Southern African Studies $42(1), 140-150$.

Leedy, D. \& Ormrod, J.E., 2001. Practical research: Planning and design, 7th edn., Merril Prentice Hall, Columbus, $\mathrm{OH}$.

Levin, M., 2005, 'Opting out of organized politics: Youth and the election', Development Update 3(2), 25-42.

Mangcu, X., 2011, Becoming worthy ancestors, Wits University Press, Johannesburg.

Mangcu, X., 2015, ' 10 Steps to develop black professors', viewed 24 February 2015, from http:www.citypress.co.za/columnists

McMillan, J.H. \& Schumacher, S., 2016, Research in education: A conceptual introduction, Pearson Education, Inc., New York.

Mouton, J., 2013, How to succeed in your master's and doctoral studies, J.L. van Schaik Publishers, Pretoria.

Neuman, W.L., 2003, Social research methods: Qualitative and quantitative approaches, Pearson Education Inc., New York.

Pieterse, G., 2004, 'Preparedness of senior phase educator in lower socio-economic schools in the Nelson Mandela Metropolitan with regard to inclusive education', unpublished Master's treatise in Education, Nelson Mandela Metropolitan University, Port Elizabeth.

Vagenas, C., 1986, 'An analysis of black consciousness in South Africa according to the theoretical criteria of a revolutionary philosophy', unpublished Master's dissertation in Political Science, University of Port Elizabeth, Port Elizabeth. 